Article

\title{
Inter-Annual Variability in Blue Whale Distribution off Southern Sri Lanka between 2011 and 2012
}

\author{
Asha de Vos ${ }^{1,2,3} *$, Charitha B. Pattiaratchi ${ }^{2, \dagger}$ and Robert G. Harcourt ${ }^{4, \dagger}$ \\ 1 Centre for Ocean Health, University of California Santa Cruz, 100 Shaffer Road, Santa Cruz, \\ CA 95060, USA
}

2 School of Environmental Systems Engineering and The Oceans Institute,

The University of Western Australia, 35 Stirling Highway, M470, Crawley, WA 6009, Australia; E-Mail: chari.pattiaratchi@uwa.edu.au

3 The Sri Lankan Blue Whale Project, 131 W.A.D. Ramanayake Mawatha, Colombo 2, Sri Lanka

4 Department of Biological Sciences, Macquarie University, North Ryde, NSW 2109, Australia; E-Mail: robert.harcourt@mq.edu.au

$\dagger$ These authors contributed equally to this work.

* Author to whom correspondence should be addressed; E-Mail: asha.devos@lincoln.oxon.org; Tel.: +1-831-600-5251.

Received: 19 December 2013; in revised form: 13 May 2014 / Accepted: 23 May 2014 / Published: 1 July 2014

\begin{abstract}
Blue whale (Balaenoptera musculus) movements are often driven by the availability of their prey in space and time. While globally blue whale populations undertake long-range migrations between feeding and breeding grounds, those in the northern Indian Ocean remain in low latitude waters throughout the year with the implication that the productivity of these waters is sufficient to support their energy needs. A part of this population remains around Sri Lanka where they are usually recorded close to the southern coast during the Northeast Monsoon. To investigate inter-annual variability in sighting locations, we conducted systematic Conductivity-Temperature-Depth (CTD) and visual surveys between January-March 2011 and January-March 2012. In 2011, there was a notable decrease in inshore sightings compared to 2009 and 2012 ( $p<0.001)$. CTD data revealed that in 2011 there was increased freshwater in the upper water column accompanied by deeper upwelling than in 2012. We hypothesise that anomalous rainfall,
\end{abstract}


along with higher turbidity resulting from river discharge, affected the productivity of the inshore waters and caused a shift in blue whale prey and, consequently, the distribution of the whales themselves. An understanding of how predators and their prey respond to environmental variability is important for predicting how these species will respond to long-term changes. This is especially important given the rapid temperature increases predicted for the semi-enclosed northern Indian Ocean.

Keywords: Balaenoptera musculus; krill; upwelling; northern Indian Ocean; inter-annual variation; climate change

\section{Introduction}

Whales live in heterogeneous ocean environments. Due to their large size and energy needs they target areas of high productivity [1]. While blue whales have low mass specific metabolic rates, their immense absolute mass requires them to exploit exceptionally dense krill aggregations to meet their overall nutritional requirements [2]. This dependence on krill makes them susceptible to environmental change as environmental variability that influences krill abundance is likely to be a driver of distributional change $[3,4]$. Relationships between predator distribution and physical or biological variables have been demonstrated in other marine species (e.g., [5-9]).

Animal migrations are often instigated by seasonal cycles of food supply [10,11]. In general, most baleen whale species undertake long-range seasonal migrations between productive high latitude feeding grounds and unproductive, low latitude breeding grounds [12,13]. However, there is evidence that blue whales also feed at mid and low latitude areas [14,15]. Blue whale populations within the northern Indian Ocean are thought not to undertake polar migrations but remain in warm low latitude waters year round [16], with a part of their population remaining resident around Sri Lanka as evidenced by year-round sightings, strandings and acoustic detections [1]. That they choose to remain resident in tropical waters suggests that there is sufficient food in the area to offset the need to migrate.

The presence of a landmass to the north of the Indian Ocean leads to unequal heating and cooling of land and sea and results in monsoonal winds, which drive the climate of the region. The Northeast Monsoon occurs between December and April and the Southwest Monsoon occurs between June and October, and they are interspersed by two inter-monsoon periods [17]. Throughout the Northeast Monsoon, the period of this study, the population of blue whales off southern Sri Lanka is seen in consistently high numbers in coastal waters, which has driven the development of a coastal whale-watch industry.

Given the importance of krill to foraging blue whales, and the close relationship between physical oceanographic variables and krill distribution, we investigated the links between salinity, sea surface temperature and blue whale distribution and abundance over the years 2009, 2011 and 2012. Cetaceans and other large mobile predators have the capacity to shift their ranges in response to changing ocean temperatures and anthropogenic threats; however, the semi-enclosed nature of the northern Indian Ocean limits northward range shifts. The implications of this spatial-confinement within the northern Indian Ocean, a geographical "cul-de-sac", make this population particularly vulnerable to oceanographic 
and human induced changes highlighting the need for understanding the dynamics of the ecological relationships within this area. If whale abundance and distribution is closely linked to movements of their prey, then we might be able to predict areas of importance through simple physical measurements of variables important to prey distribution. Therefore we compared sighting locations of blue whales from 2009, 2011, 2012 and sea surface temperature and salinity along a predetermined transect (in 2011 and 2012) during the Northeast Monsoon to observe how these physical parameters correlated with the distribution of blue whales from year to year.

\section{Methods}

\subsection{Survey Area}

Surveys for blue whales were conducted off southern Sri Lanka between Weligama and Dondra. This area encompasses a narrow, steep continental slope and a submarine canyon (Figure 1) with consistently high blue whale sightings during the Northeast Monsoon period (December-April).

Figure 1. (a) Location map of study area on the southern coast of Sri Lanka delineated by the red box. (b) Dashed lines indicate saw tooth transect tracklines in 2011 and 2012. Blue-grey vertical line directly south of Weligama Bay represents the Conductivity-Temperature-Depth (CTD) transect used to gather salinity, temperature and density data. Red arrows indicate the major east-west shipping route across the Indian Ocean from Admiralty charts.

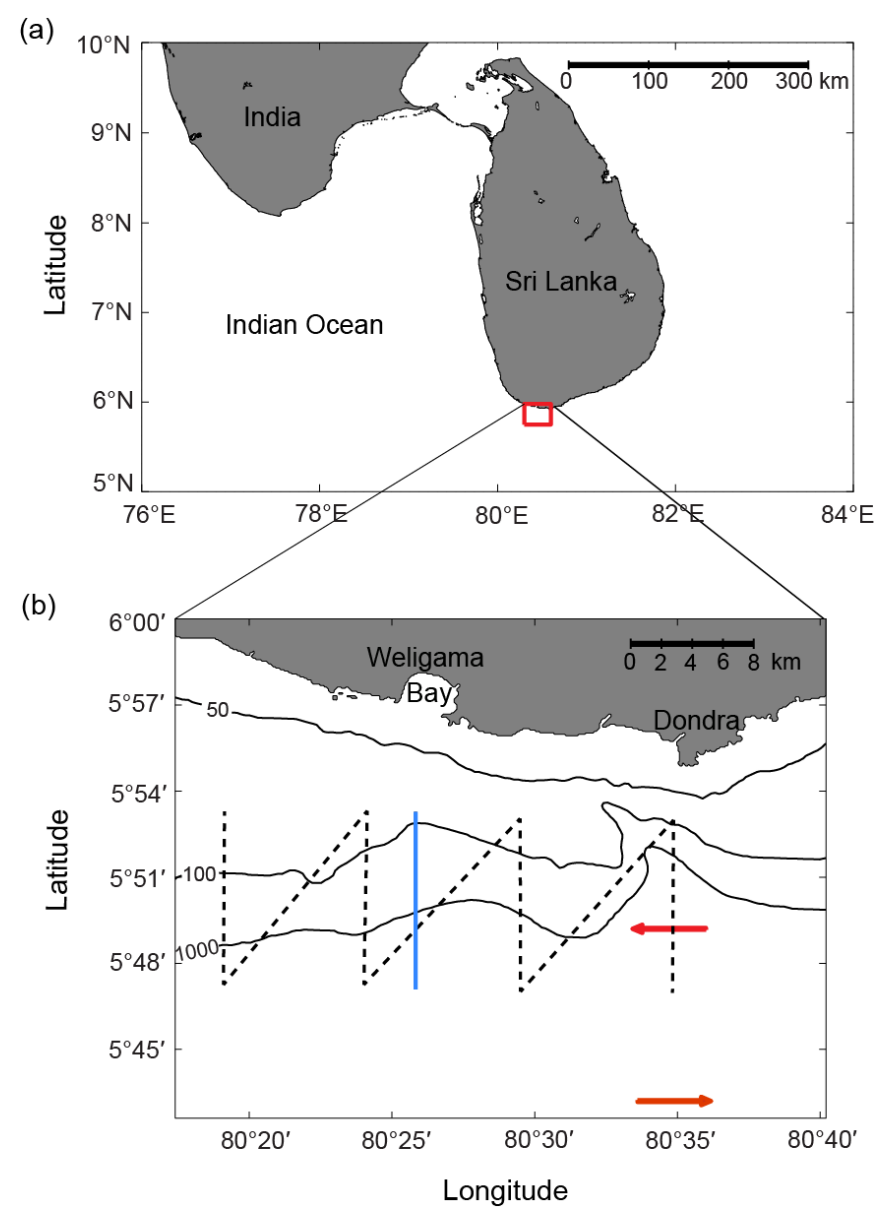




\subsection{Satellite Data}

Sea surface salinity data for the Indian Ocean were obtained from the HYCOM global hindcast model for 14 January 2009, 2011 and 2012. Seasonal (January-March 2009, 2011 and 2012) precipitation anomaly data for the waters around Sri Lanka were obtained from the NOAA Climate Prediction Center's CAMS_OPI data set. These data were used to compare ocean and climate conditions among the three years.

\subsection{Survey Methodology}

In 2009 blue whale sighting data were collected using platforms of opportunity and focal encounters, while in 2011 and 2012 surveys were conducted from dedicated platforms and data gathered through both systematic transects and opportunistic focal encounters. On 14 January 2011 and 21 January 2012 salinity and temperature data were gathered at eight stations along a predetermined transect off Weligama using a Conductivity-Temperature-Depth (CTD, YSI CastAway, San Diego, CA, USA) measure (Figure 1b). The first CTD station lay $7 \mathrm{~km}$ due south of the mouth of Weligama Bay with each of the subsequent stations located $1.65-1.75 \mathrm{~km}$ southward.

The systematic survey transect was designed to cover a range of water depths from the continental shelf to over $1000 \mathrm{~m}$, and included the continental slope and the submarine canyon off Dondra (Figure 1b). It was intended to provide an indication of blue whale distribution over the selected study area.

During all surveys conducted from the $6 \mathrm{~m}$ research vessel, a pair of observers with an eye height of $2 \mathrm{~m}$ above water level searched in an arc $180^{\circ}$ forward of the boat out to the horizon. Observations were made using the naked eye but a pair of $7 \times 40$ binoculars was available to verify sightings. Boat speed was maintained between 5 and 7 knots at all times. On sighting a whale, the time of sighting, GPS location of boat, distance and radial angle to the whale, number of individuals in the group and behaviours observed were recorded. In addition, weather and sea state data were collected at the start of the survey and whenever conditions changed significantly. Systematic surveys were only conducted when Beaufort Sea State was 2 or less and visibility was greater than $3 \mathrm{~km}$ and carried out twice over each study period. The vessel did not deviate from the trackline during these surveys and only sightings within $2 \mathrm{~km}$ of the trackline were recorded.

Blue whale sighting data were also collected during opportunistic focal follows when individuals were approached for photo-identification and for the collection of behavioural data. The protocols followed were the same as during the systematic surveys except searching did not occur over predetermined tracklines.

Salinity and temperature data were gathered over the top $100 \mathrm{~m}$ of the water column along a predetermined CTD transect with the first station located $7 \mathrm{~km}$ due south of the mouth of Weligama Bay (Figure 1b). At each of the eight stations located $1.65-1.75 \mathrm{~km}$ apart, salinity, temperature, density (sigma-t) and coordinate of cast location were collected once or twice during the study period depending on sea conditions. The YSI CastAway CTD was selected for portability and ease of hand casting from a small boat without a winch and was restricted to a maximum depth of $100 \mathrm{~m}$. 


\subsection{Data Processing and Analysis}

Blue whale sighting data were adjusted based on radial angle and distance to sighting. The data were then plotted in distribution maps of blue whale sightings using the M_Map package in MATLAB [18] representing (a) systematic surveys (2011 and 2012) and (b) opportunistic encounters (2009, 2011 and 2012).

We conducted a one-way ANOVA to look at the difference in number of whale sightings per $\mathrm{km}$ of trackline between years using the statistical package JMP. Distance from shore was calculated for each whale sighted during the opportunistic focal follows. To verify that sightings were independent, photo-identification images were used to remove repeat sightings. Distance from shore data was binned according to year and a one-way ANOVA was conducted using SYSTAT to determine if the areas where blue whales were sighted varied significantly from year to year.

Contour plots of salinity and temperature were plotted to observe changes from onshore to offshore along the transect using a script written in MATLAB. In addition, a temperature-salinity diagram was plotted to look at differences between 2011 and 2012.

\section{Results}

\subsection{Climate Influences}

HYCOM global hindcast model data of sea surface salinity indicated the presence of high salinity water between 33.5 and 34.5 PSU around Sri Lanka in 2009 and 2012 (Figure 2). In 2011 this layer was replaced by low salinity water (between 32 and 33 PSU, Figure 2). Seasonal (January-March 2009, 2011 and 2012) precipitation anomaly data from the NOAA Climate Prediction Center's CAMS_OPI data set [19] indicated the presence of low salinity water that resulted from increased precipitation levels during the 2011 season with between 300 and $600 \mathrm{~mm} / \mathrm{season}$ above average off the southern coast. In contrast, no anomalous rainfall was experienced during the same period in 2009 and 2012 (Figure 3).

Table 1. Date, effort, weather conditions and number of blue whales sighted on each systematic survey conducted in 2011 and 2012.

\begin{tabular}{lccccc}
\hline \multirow{2}{*}{ Year } & Date & $\begin{array}{c}\text { Effort } \\
\text { (Distance in } \mathbf{k m})\end{array}$ & $\begin{array}{c}\text { Effort } \\
(\mathbf{m i n})\end{array}$ & $\begin{array}{c}\text { Weather } \\
\text { (Beaufort Scale) }\end{array}$ & $\boldsymbol{n}$ \\
\hline \multirow{2}{*}{2011} & 13 January & 92 & 340 & 1 & 1 \\
& 9 February & 92 & 360 & 2 & 1 \\
\hline \multirow{2}{*}{2012} & 20 January & 92 & 367 & 2 & 41 \\
& 4 February & 92 & 393 & 1 & 25 \\
\hline
\end{tabular}

\subsection{Systematic Survey Data}

Systematic surveys were conducted twice each during 2011 and 2012 and covered a total of $368 \mathrm{~km}$. Time spent on effort in both years was comparable (Table 1). Overall few blue whales $(n=2)$ were recorded during the systematic transects in 2011. In contrast, in 2012, an increased number of whales were recorded during the surveys $(n=66)$ (Table 1 ; Figure 4$)$. A one-way analysis of variance 
revealed significant differences between the number of whales sighted per km of trackline in 2011 and 2012, $F(1,12)=24.4769, p<0.001, n=14$ (Figure 5).

Figure 2. Sea surface salinity in the Indian Ocean from (a) 14 January 2009 (b) 14 January 2011 and (c) 14 January 2012 from HYCOM global hindcast model.

(a)

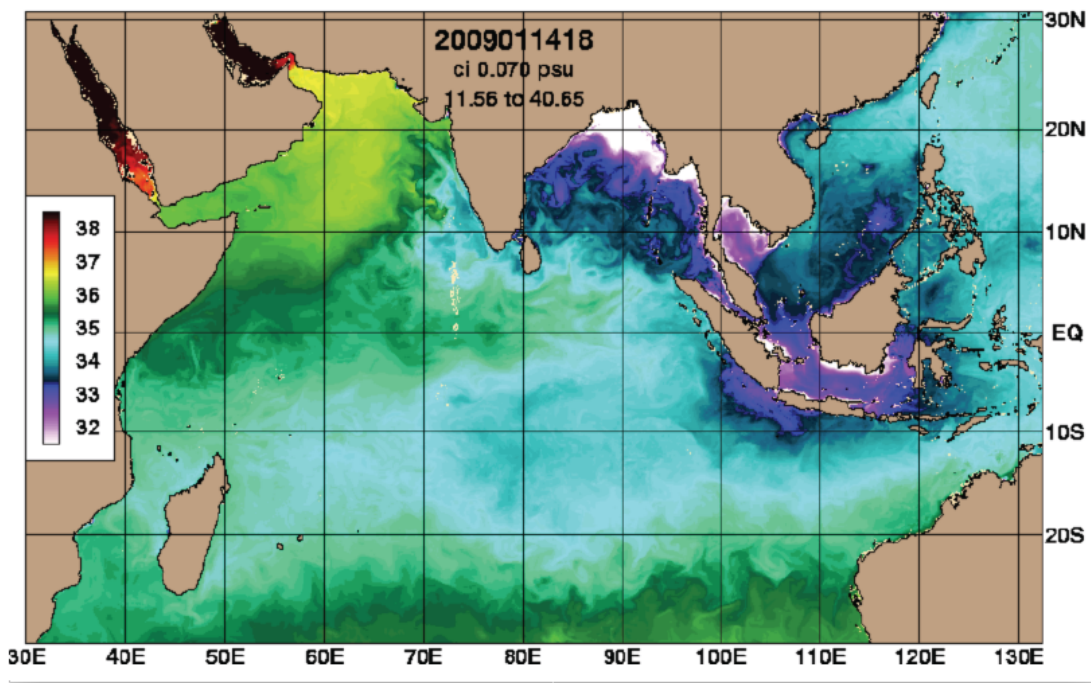

(b)

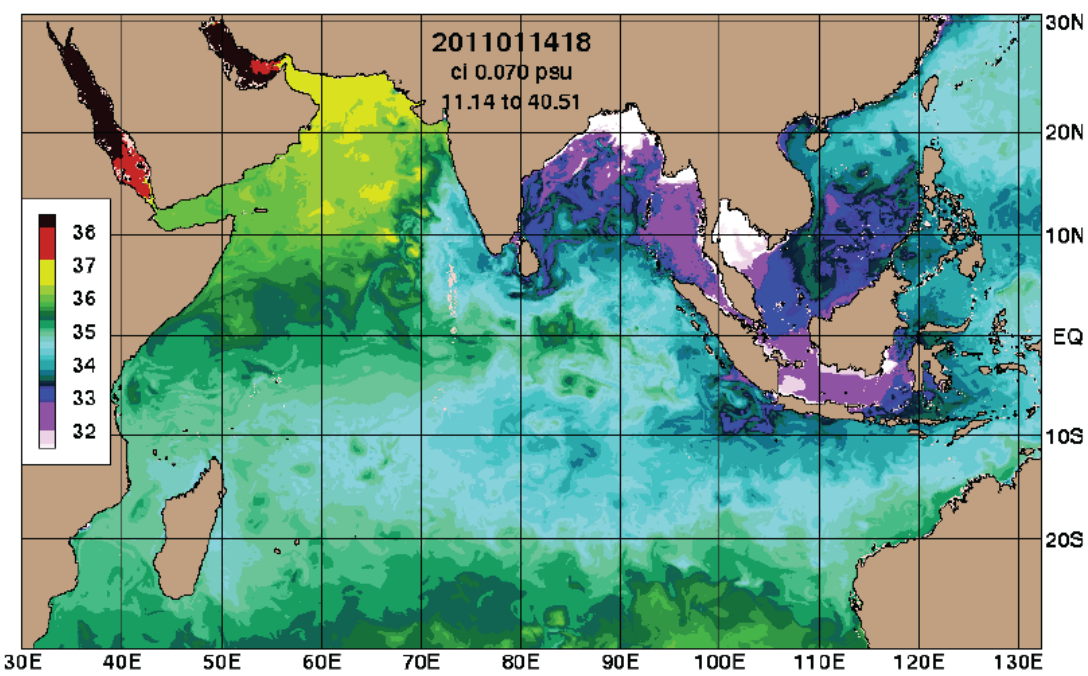

(c)

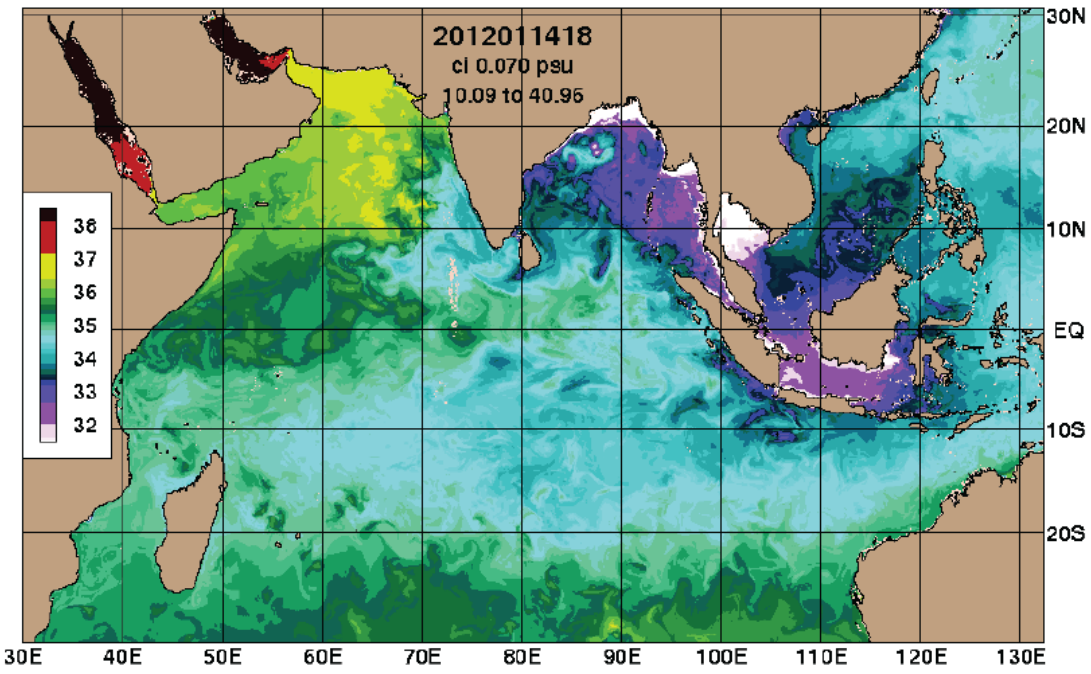


Figure 3. Seasonal precipitation anomaly around Sri Lanka for the period of (a) January-March 2009 (b) January-March 2011 and (c) January-March 2012. Green represents positive precipitation anomalies while brown represents negative precipitation anomalies.

(a)

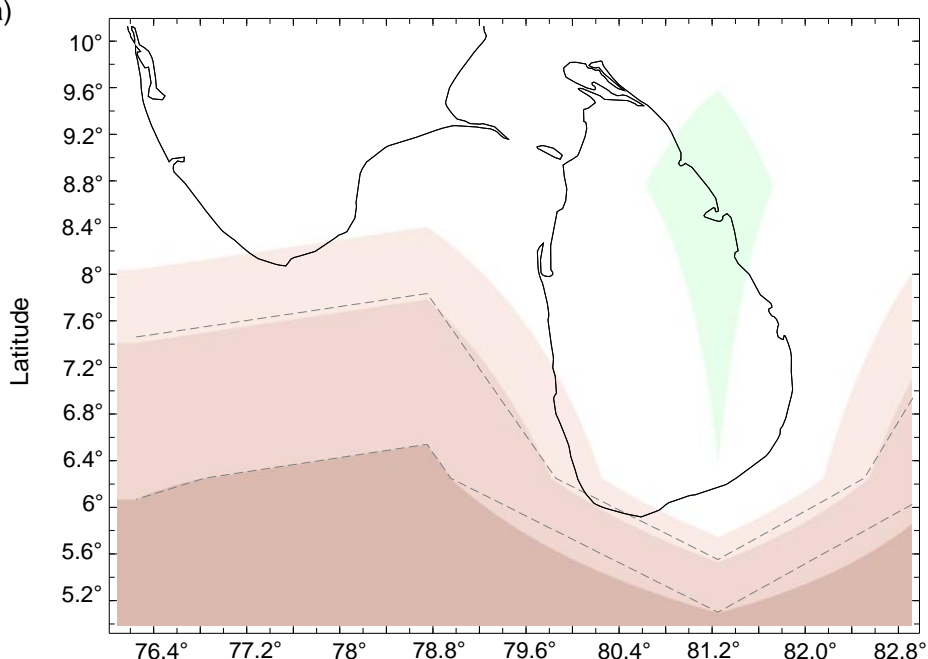

(b)

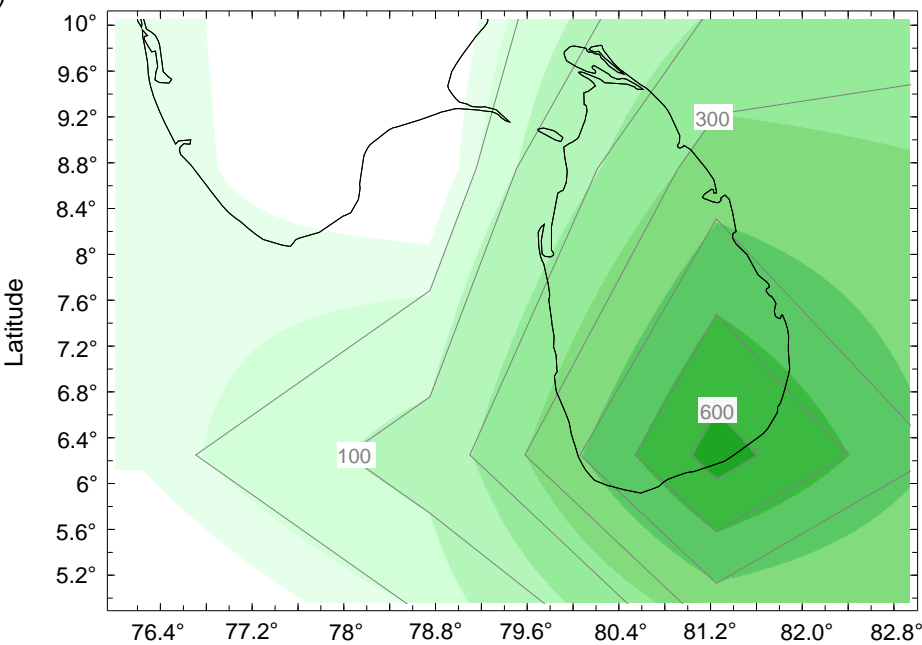

(c)
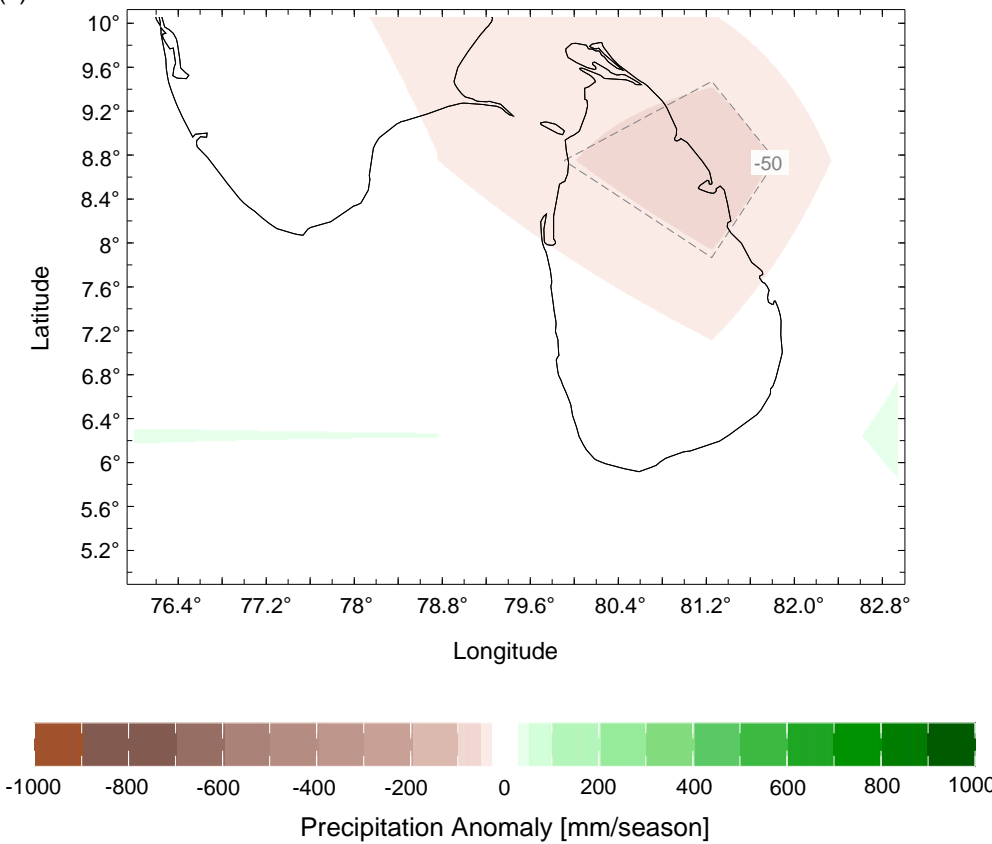
Figure 4. Blue whale distribution based on data collected during systematic transects. Orange dots indicate sightings from 2011 and purple dots indicate sightings from 2012. Dashed line indicates the vessel trackline for both years.

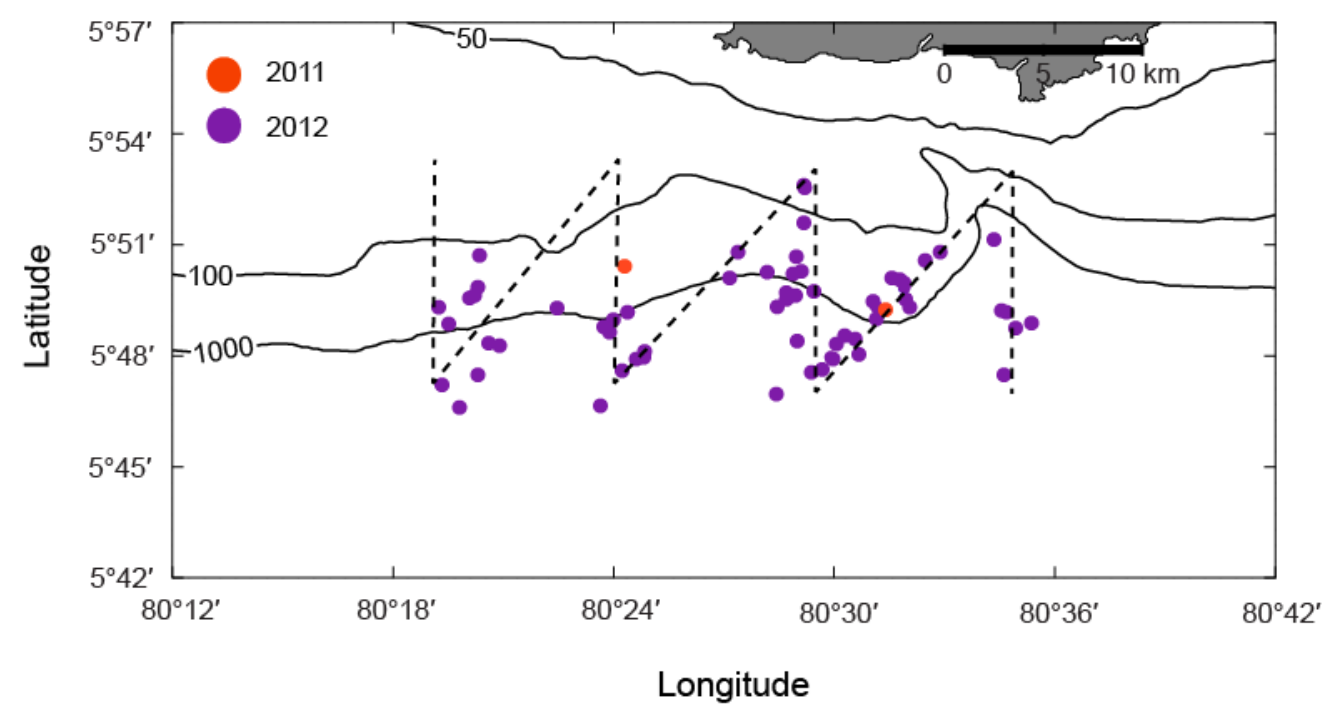

Figure 5. Mean number of whales $( \pm$ S.E.) sighted per km of trackline.

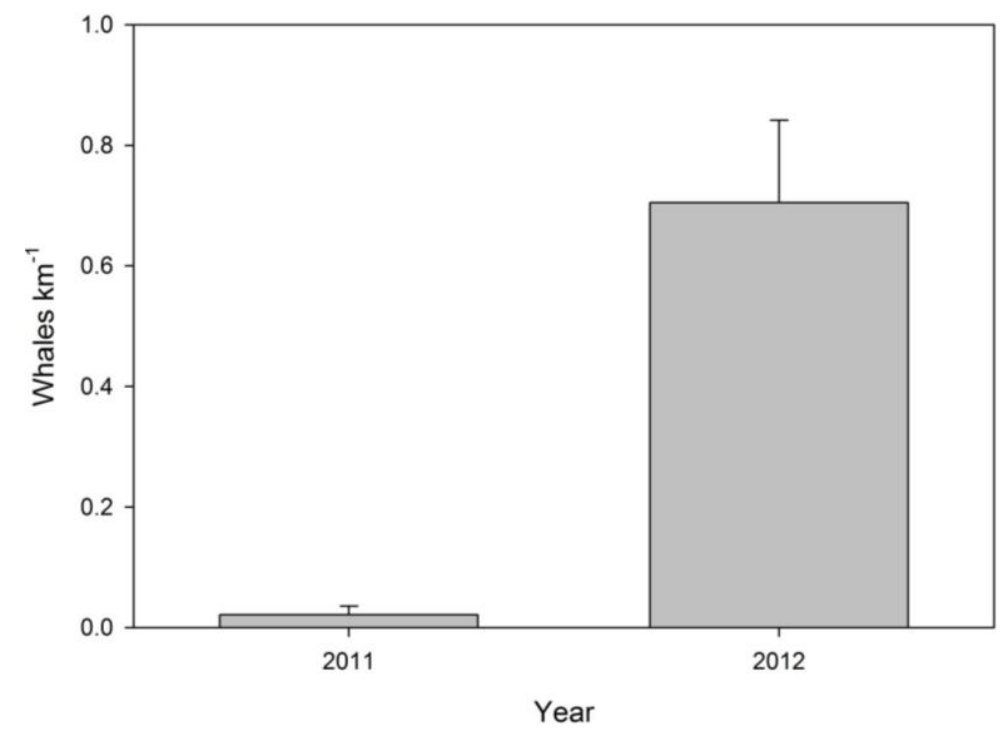

\subsection{Opportunistic Sighting Data}

In 2009 and 2012, blue whales were seen largely between the 100 and 1000 m contours with fewer sightings in depths ranging to about $1500 \mathrm{~m}$. In 2011 however, the majority of sightings occurred further offshore, in waters exceeding $1500 \mathrm{~m}$, and were spread over a greater area (Table 2; Figure 6). In all three years, opportunistic photo-identification/focal encounters targeted groups that were closest inshore. Therefore the reduced opportunistic sightings in inshore areas in 2011 likely indicate a real shift in blue whale distribution to offshore areas and are representative of the actual spread of whales.

A one-way analysis of variance revealed significant differences between mean distances from shore over the three years, $F(2,209)=40.416, p<0.0001, n=212$. Post-hoc comparisons using Tukey's HSD revealed that in 2011 whales were seen significantly further offshore than in 2009 and 2012. 
Table 2. Percentage of opportunistic blue whale sightings in waters $\leq 1000 \mathrm{~m} \mathrm{vs}$. $>1000 \mathrm{~m}$ depth and mean distance from shore for 2009, 2011 and 2012.

\begin{tabular}{ccccc}
\hline Year & $\boldsymbol{n}$ & $\mathbf{\leq 1 0 0 0} \mathbf{~ m}$ & $\mathbf{> 1 0 0 0} \mathbf{~ m}$ & Mean Distance from Shore $(\mathbf{k m})$ \\
\hline 2009 & 53 & $79 \%$ & $21 \%$ & 11.8 \\
2011 & 39 & $20 \%$ & $80 \%$ & 16.6 \\
2012 & 176 & $82 \%$ & $18 \%$ & 11.6 \\
\hline
\end{tabular}

Figure 6. Blue whale sightings from 2009 (grey), 2011 (orange) and 2012 (purple). Each dot represents an individual sighting. All sightings were from first encounter of an individual on each day.

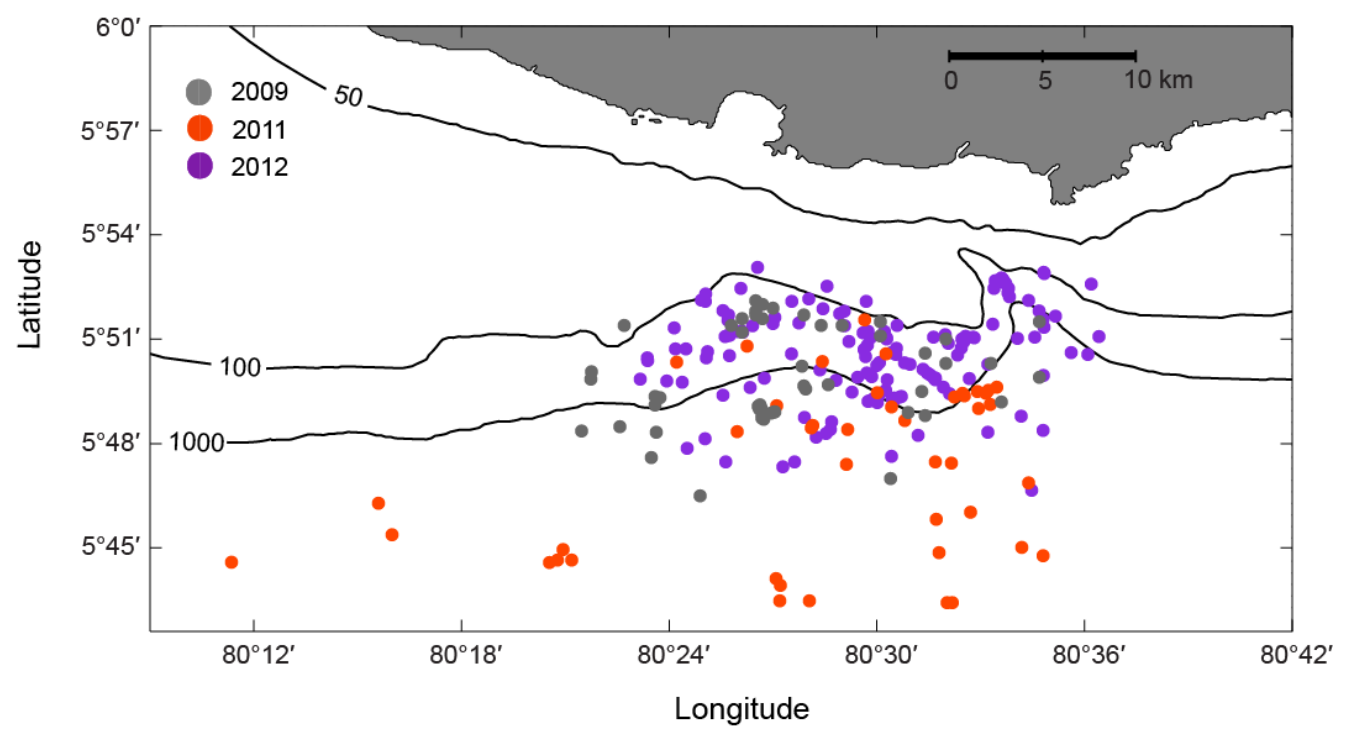

\subsection{Temperature and Salinity Data}

The salinity and temperature contour plots for the two years indicated that in January 2012 cooler waters, characterised by the $24.5^{\circ} \mathrm{C}$ contour, upwelled onto the shelf at a depth of approximately $60 \mathrm{~m}$. In 2011 this water mass was recorded at $80 \mathrm{~m}$ (Figure 7). In 2012 the top $45 \mathrm{~m}$ of the water column was relatively well mixed and ranged from 27 to $28{ }^{\circ} \mathrm{C}$, while in 2011 it was more stratified with surface waters at $26.5{ }^{\circ} \mathrm{C}$ and the $28{ }^{\circ} \mathrm{C}$ layer occurring as a sub-surface maximum at $65 \mathrm{~m}$. Further, the top $85 \mathrm{~m}$ of the water column was fresher during 2011 compared to 2012. In 2011 salinity in the top $65 \mathrm{~m}$ of the water column ranged from 31.5 to 33 whilst in 2012 the layer of 33 PSU salinity water occurred much shallower, at $40 \mathrm{~m}$. In 2011 the salinity of the water column in the top $100 \mathrm{~m}$ reached 33.5 while in 2012 it reached 35 (Figure 7). The lower salinity water (31.5 PSU) close to shore extending $8 \mathrm{~km}$ from the start of the CTD transect is a feature documented only in 2011 and can be described as a "freshwater cap".

The marked differences in salinity and temperature between the two years are evident in Figure 8 . The temperature-salinity plot shows that in 2011 temperature in the water column was uniform (over a $0.6{ }^{\circ} \mathrm{C}$ range) over a wider salinity range-from 30.5 to 33.5 PSU. However, in 2012 salinity showed less variation (ranging 1.2 PSU) while temperature covered a wider $1.7^{\circ} \mathrm{C}$ range. 
Figure 7. Contour plots for temperature, salinity and density (measured in sigma-t) for the two contrasting years; (a) 2011 and (b) 2012.

(a)
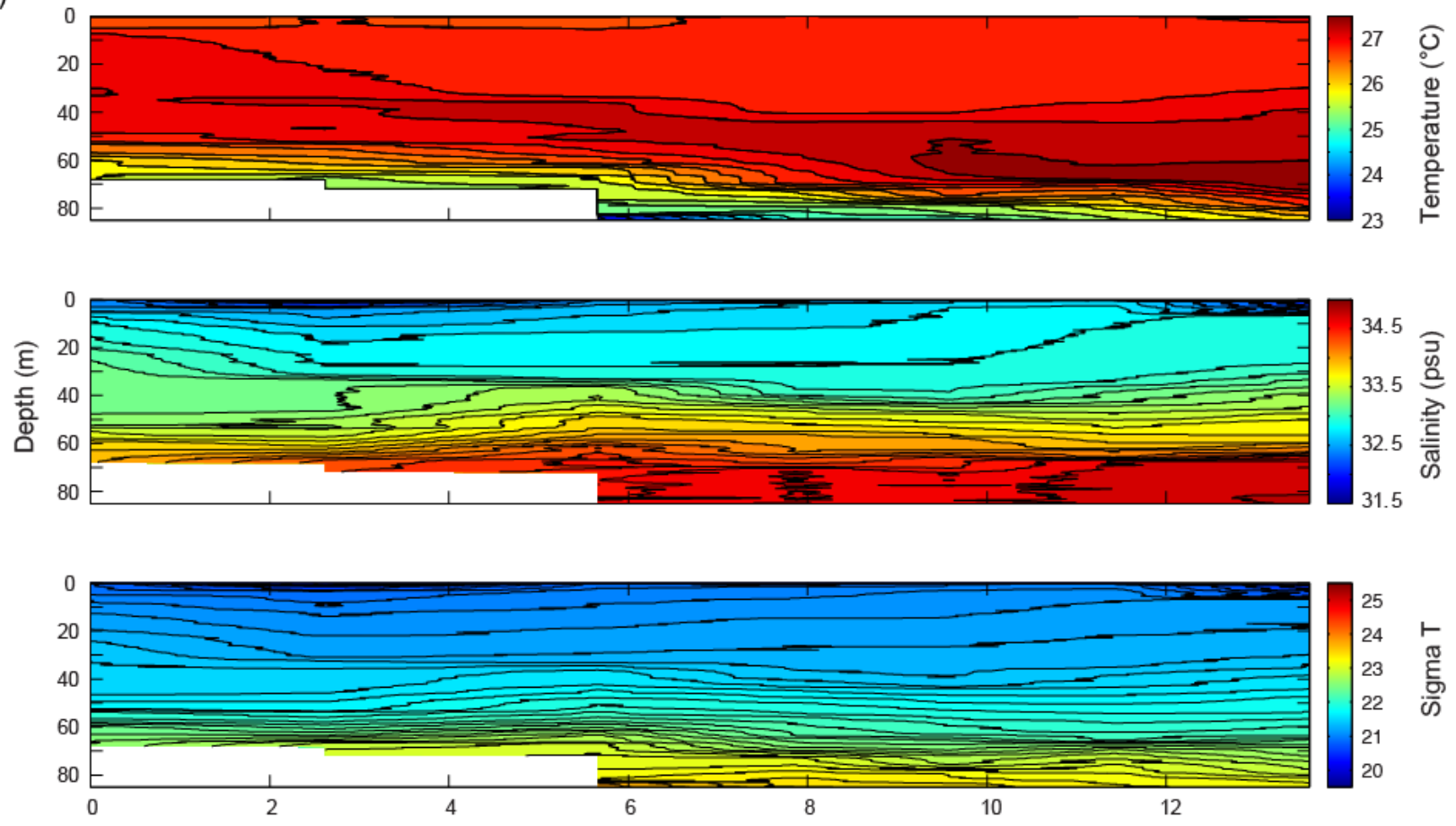

(b)
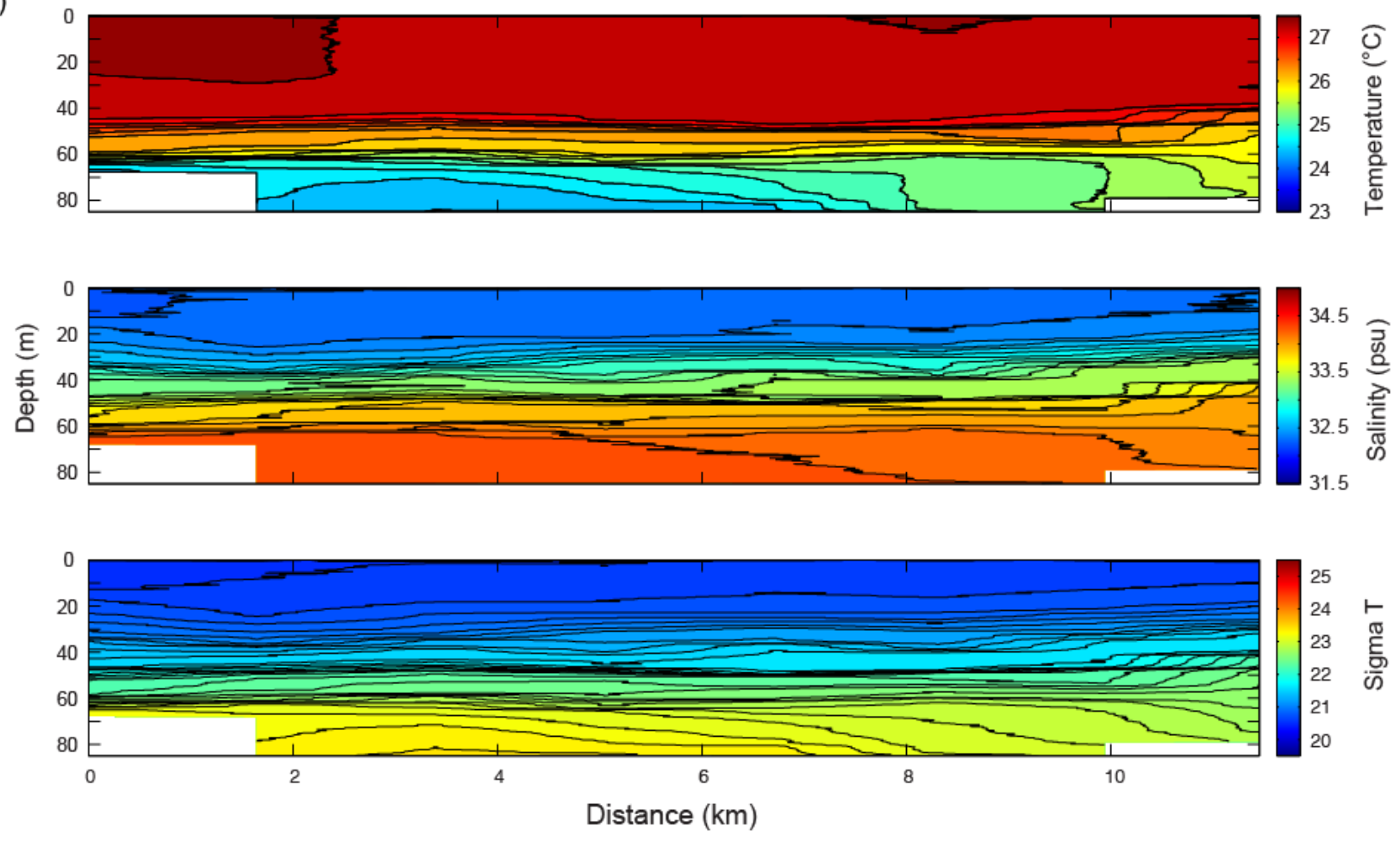
Figure 8. Temperature-salinity plot for mean of cast 2 along the transect in 2011 (solid black) and 2012 (dashed black).

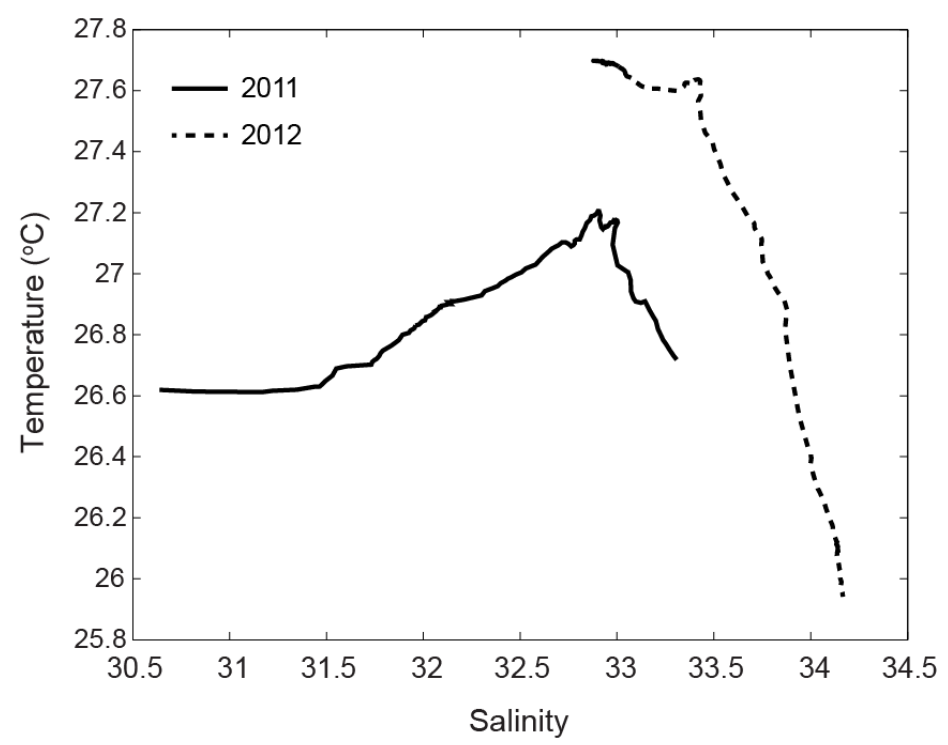

\section{Discussion}

Our results suggest that blue whale distribution off southern Sri Lanka may have been influenced by anomalous rainfall resulting in excessive freshwater runoff through river discharge into the coastal waters. Of the 103 river basins around Sri Lanka, the Nilwala Ganga that discharges into our study area, is vulnerable to floods [20] and is the main source of freshwater to the nearshore areas. The high precipitation anomaly that led to island-wide flooding that displaced and killed many people around Sri Lanka during the Northeast or Winter Monsoon of 2011 has been linked with the La Niña that results from episodic cooling in the equatorial Pacific Ocean [21]. The 2010/2011 La Niña is considered one of the strongest recorded over the past eight decades [22].

Increased freshwater runoff is a likely cause of change in blue whale distribution in 2011. The influence of the floodwater within the study area in 2011 is evident from the salinity contour plot (Figure 7) as the layer of freshwater at the surface is $\sim 30.5$ PSU. This is below the salinity range of water from the Bay of Bengal (33.5-35 PSU above $25{ }^{\circ} \mathrm{C}$; [23]) which influences the surface waters south of Sri Lanka during this period [23,24]. The distributional shift was apparently temporary as blue whales returned to the nearshore areas in 2012, which was a drier year.

We hypothesise that the abundant freshwater decreased salinity and likely increased turbidity in the water column. The presence of the freshwater layer in the upper water column in 2011 appeared to cause the cooler, $24.5{ }^{\circ} \mathrm{C}$ water to occur approximately $20 \mathrm{~m}$ deeper than in 2012 . Therefore this freshwater cap may potentially influence the productivity of the area.

The nearshore water was often greener and fresher with offshore waters being darker blue and more saline. Distinct fronts could be seen between these water masses in some areas (Figure 9). Over the course of this study we did not record blue whales in the greener, fresher water, with all sightings occurring in the more saline waters. This contrasts with earlier reports as Alling et al. [25] recorded an equal number of blue whales within and outside a river plume off the northeast coast of Sri Lanka on one day in 1984. 
Figure 9. Image taken within study area showing distinct freshwater front between higher salinity dark blue water (foreground) and lower salinity greener water with higher turbidity (background).

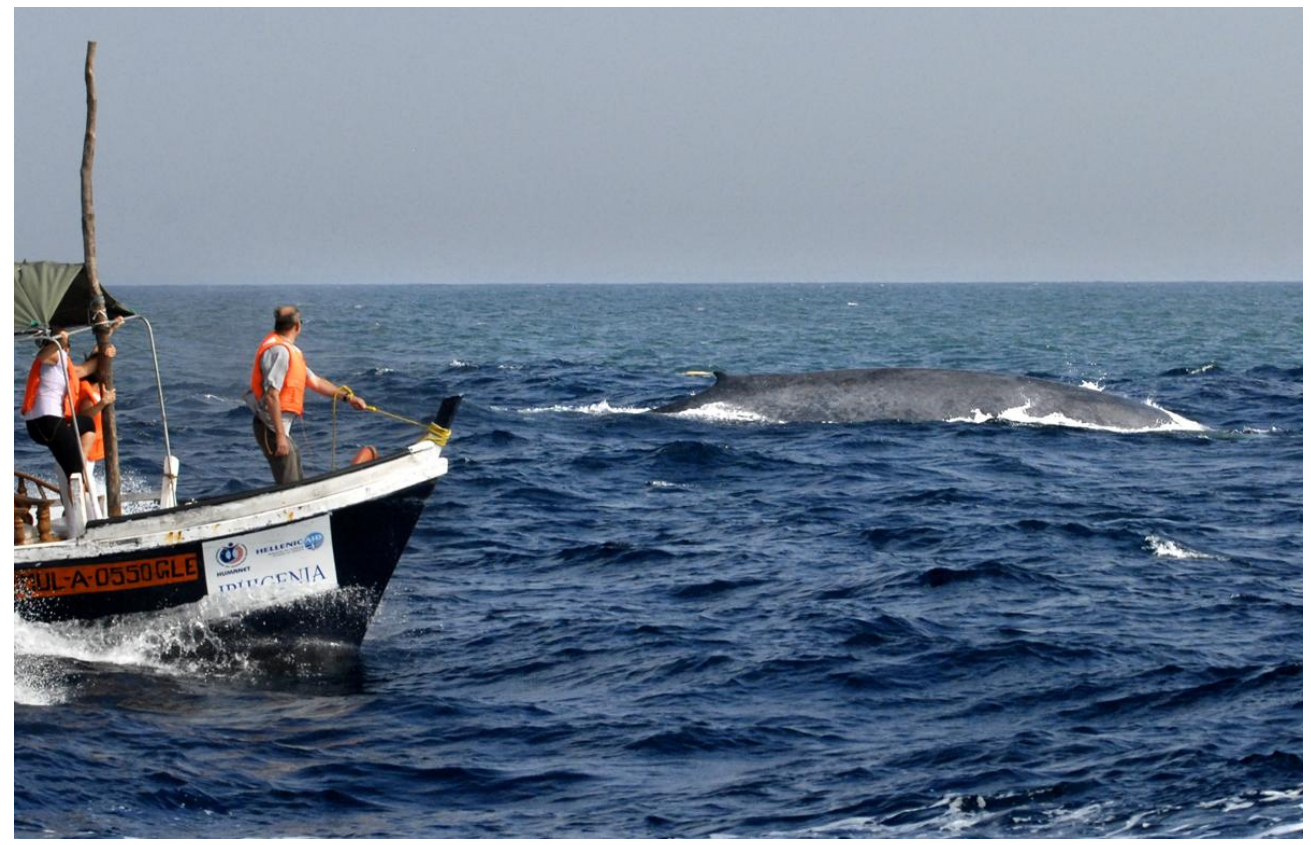

While the direct impact of freshwater runoff is restricted to the upper few metres of the water column, it modifies the structure and dynamics of the physical environment by modulating stratification, circulation and nutrient input, as well as the vertical distribution and production of plankton [26-28]. Marine species distributions have been specifically associated with a number of variables such as sea surface temperature and salinity. Rutherford et al. [29] found that approximately $90 \%$ of the geographic variation seen in planktic foraminiferal diversity in the Atlantic was explained by sea surface temperature. Salinity or turbidity related to river outputs was cited as a possible influence on diversity in the Western tropical Atlantic [29]. In the Atlantic and Pacific, salinity is also considered a significant predictor of euphausiid species abundance particularly in coastal and fjordic systems, where river outputs impact salinity [30]. Calliari et al. [31] showed that instantaneous salinity reductions compromised the survival and feeding rates of two species of co-occurring copepods. They suggest that decreased feeding rate may have direct implications for processes at both the individual level, in relation to energy acquisition, and the ecosystem level, in relation to the transfer of organic matter.

The offshore shift in blue whale sightings in 2011 compared to 2008/2009 was also commented on by Ilangakoon [32]. Ilangakoon [32] suggested that this distributional change was connected to newly established commercial whale-watch activities and asserts that this shift increased the likelihood of ship strike of these whales. We suggest that the shift is more likely a function of oceanographic change rather than being anthropogenically induced. Furthermore, unlike small cetaceans, little conclusive evidence exists to show that large baleen whales are affected by the presence of whale-watch vessels. Recent meta-analyses by Senigaglia et al. [33] did not show any changes in respiration rate in the presence of whale-watch boats. Similarly, blue whales in Sri Lankan waters did not display changes in fluking behaviour in the presence of whale-watch boats [34]. Secondly, in 2012 there was an increase in the number of whale-watching boats on the water compared to 2011 [35]. If the offshore shift was a 
function of whale-watching alone then we would have expected it to persist through to 2012. The major Indian Ocean shipping lanes lie off the southern coast of Sri Lanka with separation zones extending approximately $10 \mathrm{~km}$ to $30 \mathrm{~km}$ offshore [36] (Figure 1b), blue whales are consistently recorded within the shipping lanes in all years and ship strikes are known to occur and have been highlighted as a major concern [37]. Changes in the onshore-offshore distribution of whales such as those documented here likely affect the risk of collisions between whales and shipping, which may be relevant to efforts to mitigate this problem.

Other studies have highlighted the influence of climatic events such as El Niño, La Niña and the North Atlantic Oscillation index on different levels of the food chain [38-41]. Changes in abundance and diversity and species richness patterns have also been documented for a variety of taxa [41-44]. A study by Reilly and Fiedler [45] found that inter-annual variation in dolphin distribution related to shifts in preferred habitat that reflected El Niño Southern Oscillation (ENSO) cycles. The distribution and abundance of baleen whales on the eastern Bering Sea shelf also changed between 1999 and 2004 as a result of corresponding temperature increases over this period [46]. Littaye et al. [47] showed that fin whales adapted their movements and group size to food availability which was driven by the environmental conditions in the preceding months, while off Monterey Bay, California, 12 commonly sighted species of marine mammals redistributed annually depending on the prevailing environmental conditions [48]. In El Niño years, when basin-wide decreases in primary production were documented, marine mammals would move from offshore to nearshore areas because of the relatively greater productivity, while during localised events marine mammals, including blue whales, redistributed to the areas influenced by the anomaly [48].

Our results are based on only two years of systematic sampling and three years of opportunistic data; however, we acknowledge that to better understand longer-term variability in the environment, sustained monitoring over multiple years is essential. An improved understanding of changes in the distribution of top predators is important in light of global climate change and the subsequent effects on the ocean. Specifically, an understanding of how different environmental and oceanographic changes influence prey distribution and the blue whale populations off Sri Lanka will provide insight into the response of this little known population of blue whales to future environmental variability.

\section{Conclusions}

Dedicated visual surveys coupled with salinity and temperature measurements, identified a correlation between the reduced inshore sightings of blue whales and increased freshwater discharge from rivers, as a result of anomalous rainfall in 2011. We hypothesise that the freshwater run off during the 2011 survey season may have increased turbidity and thereby influenced productivity in the nearshore waters. An understanding of how predators respond to environmental variability is important to predict how they will respond to long-term changes. This is especially important given the predicted global climate changes that may affect the semi-enclosed northern Indian Ocean.

\section{Acknowledgments}

All research reported in this manuscript was conducted under a Department of Wildlife Conservation, Sri Lanka permit (number WL/3/2/1/18). The fieldwork was conducted with funds from 
the Ocean Park Conservation Foundation, Hong Kong, a University of Western Australia (UWA) Research Collaboration Award and a Duke University Global Fellows' mini grant. The funding sources had no involvement in any part of the data collection or manuscript preparation. AdV is supported by a UWA Scholarship for International Research Fees (SIRF) and a UWA Convocation Travel Award. The authors wish to thank the following individuals for support in the field: Andrew Willson, Archer Wong, Matthew Tam, Matthew Bowers, Jerry Moxley, Nihal, Udaya, Lahiru, Prabath and Nuwan. The authors also wish to thank two anonymous reviewers for their valuable comments on previous versions of this manuscript.

\section{Author Contributions}

Conceived and designed the surveys: AdV CBP RGH. Conducted field-work: AdV. Analysed the data: AdV. Wrote the paper: AdV CBP RGH.

\section{Conflicts of Interest}

The authors declare no conflict of interest.

\section{References}

1. Branch, T.A.; Stafford, K.M.; Palacios, D.M.; Allison, C.; Bannister, J.L.; Burton, C.L.K.; Cabrera, E.; Carlson, C.A.; Vernazzani, B.G.; Gill, P.C.; et al. Past and present distribution, densities and movements of blue whales Balaenoptera musculus in the Southern Hemisphere and northern Indian Ocean. Mammal Rev. 2007, 37, 116-175.

2. Goldbogen, J.A.; Calambokidis, J.; Oleson, E.; Potvin, J.; Pyenson, N.D.; Schorr, G.; Shadwick, R.E. Mechanics, hydrodynamics and energetics of blue whale lunge feeding: Efficiency dependence on krill density. J. Exp. Biol. 2011, 214, 131-146.

3. Fiedler, P.C.; Reilly, S.B.; Hewitt, S.B.; Demer, D.; Philbrick, V.A.; Smith, S.; Armstrong, W.; Croll, D.A.; Tershy, B.R.; Mate, B.R. Blue whale habitat and prey in the California Channel Islands. Deep Sea Res. Part II: Top. Stud. Oceanogr. 1998, 45, 1781-1801.

4. Boucher, J.; Ibanez, F.; Prieur, L. Diel and seasonal variations in the spatial distribution of zooplankton populations in relation to the physical structure of the Ligurian Sea front. J. Mar. Res. 1987, 45, 133-173.

5. Guinet, C.; Dubroca, L.; Lea, M.A.; Goldsworthy, S.; Cherel, Y.; Duhamel, G.; Bonadonna, F.; Donnay, J.P. Spatial distribution of foraging in female Antarctic fur seals Arctocephalus gazella in relation to oceanographic variables: A scale-dependent approach using geographic information systems. Mar. Ecol. Prog. Ser. 2001, 219, 251-264.

6. Reid, K. An initial examination of relationships between the distribution of whales and Antarctic krill, Euphausia superba at South Georgia. J. Cetacean Res. Manag. 2000, 2, 143-149.

7. Murase, H.; Matsuoka, K.; Ichii, T.; Nishiwaki, S. Relationship between the distribution of euphausiids and baleen whales in the Antarctic ( $\left.35^{\circ} \mathrm{E}-145^{\circ} \mathrm{W}\right)$. Polar Biol. 2002, 25, 135-145.

8. Ballance, L.T.; Pitman, R.L.; Fiedler, P.C. Oceanographic influences on seabirds and cetaceans of the eastern tropical Pacific: A review. Prog. Oceanogr. 2006, 69, 360-390. 
9. Friedlaender, A.; Halpin, P.H.; Qian, S.S.; Wiebe, P.H.; Thiele, D.; Read, A.J. Whale distribution in relation to prey abundance and oceanographic processes in the Western Antarctic Peninsula shelf waters. Mar. Ecol. Prog. Ser. 2006, 317, 297-310.

10. Alerstam, T.; Hedenstrom, A.; Akesson, S. Long-distance migration: Evolution and determinants. Oikos 2003, 103, 247-260.

11. Dingle, H. Migration: The Biology of Life on the Move; Oxford University Press: Oxford, UK, 1996.

12. Corkeron, P.J.; Connor, R.C. Why do baleen whales migrate? Mar. Mammal Sci. 1999, 15, 1228-1245.

13. Brodie, P.F. Cetacean energetics, an overview of intraspecific size variation. Ecology 1975, 56, $152-161$.

14. Silva, M.A.; Prieto, R.; Jonsen, I.; Baumgartner, M.F.; Santos, R.S. North Atlantic blue and fin whales suspend their spring migration to forage in middle latitudes: Building up energy reserves for the journey? PLoS One 2013, 8, e76507.

15. Reilly, S.B.; Thayer, V.G. Blue whale (Balaenoptera musculus) distribution in the eastern tropical Pacific. Mar. Mammal Sci. 1990, 6, 265-277.

16. Samaran, F.; Stafford, K.M.; Branch, T.A.; Gedamke, J.; Royer, J.-Y.; Dziak, R.P.; Guinet, C. Seasonal and geographic variation of southern blue whale subspecies in the Indian Ocean. PLoS One 2013, 8, e71561.

17. De Vos, A.; Pattiaratchi, C.B.; Wijeratne, E.M.S. Surface circulation and upwelling patterns around Sri Lanka. Biogeosci. Discuss. 2013, 10, 14953-14998.

18. Pawlowicz, R. M_Map: A mapping package for Matlab. Available online: http://www.eos.ubc.ca/ rich/map.html (accessed on 1 July 2013).

19. Janowiak, J.E.; Xie, P. CAMS_OPI: A global satellite-rain gauge merged product for real-time precipitation monitoring applications. J. Clim. 1999, 12, 3335-3342.

20. Dias, P.P.G. Hydrometric network and flood mitigation. In Proceedings of the ITU Workshop on Emergency Telecommunication for Disaster Management, Colombo, Sri Lanka, 23 March 2006.

21. Allan, R.P. Climate change: Human influence on rainfall. Nature 2011, 470, 344-345.

22. Boening, C.; Willis, J.K.; Landerer, F.W.; Steven Nerem, R.; Fasullo, J. The 2011 La Niña: So strong, the oceans fell. Geophys. Res. Lett. 2012, 39, doi:10.1029/2012GL053055.

23. Schott, F.A.; McCreary, J.P., Jr. The monsoon circulation of the Indian Ocean. Prog. Oceanogr. 2001, 51, 1-123.

24. Schott, F.; Reppin, J.; Fischer, J.; Quadfasel, D. Currents and transports of the monsoon current south of Sri Lanka. J. Geophys. Res.-Oceans 1994, 99, 25127-25141.

25. Alling, A.K.; Dorsey, E.M.; Gordon, J.C.D. Blue whales (Balaenoptera musculus) off the Northeast coast of Sri Lanka: Distribution, feeding and individual identification. In Cetaceans and Cetacean Research in the Indian Ocean Sanctuary: Marine Mammal Technical Report 3; Leatherwood, S., Donovan, G.P., Eds.; United Nations Environment Programme Oceans and Coastal Areas Programme Activity Centre: Nairobi, Kenya, 1991; pp. 247-258.

26. Farmer, D.M.; Freeland, H.J. The physical oceanography of fjords. Prog. Oceanogr. 1983, 12, 147-219. 
27. Smetacek, V.S. Impact of freshwater discharge on production and transfer of materials in the marine environment. NATO ASI Ser. 1986, 7, 85-106.

28. Learmonth, J.A.; Macleod, C.D.; Santos, M.B.; Pierce, G.J.; Crick, H.Q.P.; Robinson, R.A. Potential effects of climate change on marine mammals. In Oceanography and Marine Biology: An Annual Review; Gibson, R.N., Atkinson, R.J.A., Gordon, J.D.M., Eds.; Taylor and Francis: Boca Raton, FL, USA, 2006; Volume 44.

29. Rutherford, S.; D'Hondt, S.; Prell, W. Environmental controls on the geographic distribution of zooplankton diversity. Nature 1999, 400, 749-753.

30. Letessier, T.B.; Cox, M.J.; Brierley, A.S. Drivers of variability in Euphausiid species abundnace throughout the Pacfic Ocean. J. Plankton Res. 2011, 33, 1342-1357.

31. Calliari, D.; Andersen Borg, M.C.; Thor, P.; Gorokhova, E.; Tiselius, P. Instantaneous salinity reductions affect the survival and feeding rates of the co-occurring copepods Acartia tonsa Dana and A. clausi Giesbrecht differently. J. Exp. Mar. Biol. Ecol. 2008, 362, 18-25.

32. Ilangakoon, A. Exploring anthropogenic activities that threaten endangered blue whales (Balaenoptera musculus) off Sri Lanka. J. Mar. Anim. Ecol. 2012, 5, 3-7.

33. Senigaglia, V.; Bejder, L.; Christiansen, F.; Gendron, D.; Lundquist, D.; Noren, D.; Schaffar, A.; Smith, J.C.; Williams, R.; Lusseau, D. Meta-analasyes of whalewatching impact studies: Differences and similarities in disturbance responses among species. In Proceedings of the 20th Biennial Conference on the Biology of Marine Mammals, Dunedin, New Zealand, 9-13 December 2013.

34. De Vos, A.; Christiansen, F.; Harcourt, R.G.; Pattiaratchi, C.B. Surfacing characteristics and diving behaviour of blue whales in Sri Lankan waters. J. Exp. Mar. Biol. Ecol. 2013, 449, 149-153.

35. de Vos, A. The Sri Lankan Blue Whale Project, Colombo, Sri Lanka. 2014, Unpublished work.

36. Kaluza, P.; Kolzsch, A.; Gastner, M.T.; Blasius, B. The complex network of global cargo ship movements. J. R. Soc. Interface 2010, 7, 1093-1103.

37. De Vos, A.; Wu, T.; Brownell, R.L., Jr. Recent Blue Whale Deaths due to Ship Strike around Sri Lanka; Report of the IWC Conservation Committee 2013, SC/65a/HIM03; International Whaling Commission: Cambridge, UK.

38. Drinkwater, K.F.; Belgrano, A.; Borja, A.; Conversi, A.; Edwards, M.; Greene, C.H.; Ottersen, G.; Pershing, A.J.; Walker, H. The response of marine ecosystems to climate variability associated with the North Atlantic Oscillation. In The North Atlantic Oscillation: Climatic Significance and Environmental Impact; Geophysical Monograph Series 2002; American Geophysical Union: Washington, DC, USA; pp. 211-234.

39. Barber, R.T.; Chavez, F.P. Biological consequences of El Niño. Science 1983, 222, 1203-1210.

40. Beaugrand, G.; Reid, P.C.; Ibanez, F.; Lindley, J.A.; Edwards, M. Reorganisation of North Atlantic marine copepod biodiveristy and climate. Science 2002, 296, 1692-1694.

41. Benson, S.R.; Croll, D.A.; Marinovic, B.B.; Chavez, F.P.; Harvey, J.T. Changes in the cetacean assemblage of a coastal upwelling ecosystem during El Niño 1997-98 and La Niña 1999. Prog. Oceanogr. 2002, 54, 279-291. 
42. Burtenshaw, J.C.; Oleson, E.M.; Hildebrand, J.A.; McDonald, M.A.; Andrew, R.K.; Howe, B.M.; Mercer, J.A. Acoustic and satellite remote sensing of blue whale seasonality and habitat in the Northeast Pacific. Deep-Sea Res. Part II-Top. Stud. Oceanogr. 2004, 51, 967-986.

43. Worm, B.; Sandow, M.; Oschlies, A.; Lotze, H.K.; Myers, R.A. Global patterns of predator diversity in the open oceans. Science 2005, 309, 1365-1369.

44. Hooff, R.C.; Peterson, W.T. Copepod biodiversity as an indicator of changes in ocean and climate conditions of the northern California current ecosystem. Limnol. Oceanogr. 2006, 51, 2607-2620.

45. Reilly, S.B.; Fiedler, P.C. Interannual variability of dolphin habitats in the eastern tropical Pacific. I: Research vessel surveys, 1986-1990. Fish. Bull. 1994, 92, 434-450.

46. Friday, N.A.; Waite, J.M.; Zerbini, A.N.; Moore, S.E. Cetacean distribution and abundance in relation to oceanographic domains on the eastern Bering Sea shelf: 1999-2004. Deep Sea Res. Part II: Top. Stud. Oceanogr. 2012, 65-70, 260-272.

47. Littaye, A.; Gannier, A.; Laran, S.; Wilson, J.P.F. The relationship between summer aggregation of fin whales and satellite-derived environmental conditions in the northwestern Mediterranean Sea. Remote Sens. Environ. 2004, 90, 44-52.

48. Burrows, J.A.; Harvey, J.T.; Newton, K.M.; Croll, D.A.; Benson, S.R. Marine mammal response to interannual variability in Monterey Bay, California. Mar. Ecol. Prog. Ser. 2012, 461, 257-271.

(C) 2014 by the authors; licensee MDPI, Basel, Switzerland. This article is an open access article distributed under the terms and conditions of the Creative Commons Attribution license (http://creativecommons.org/licenses/by/3.0/). 